\title{
Reflections on Threads, war and conflict: arpilleras in Chile and in International Relations
}

\author{
Authors: Rachel Beattie $\nabla$, Frankie $\operatorname{Copp} \nabla$, Schoutje Schouten $\nabla$, University of \\ St Andrews, UK
}

Rachel Beattie holds an MLitt in International Security Studies and an MA in International Relations and Modern History, both from the University of St Andrews. Her research interests draw upon Critical Security Studies with a focus on the Copenhagen School's securitisation framework. Exploring the interplay between spatiality, sound, silence and sensory experience, her work seeks to contribute to broadening understandings of "voice" and engagement, and advocate the importance of experience and everyday practices within the study of International Relations.

Frankie Copp holds an MLitt in International Security Studies from the University of St Andrews and a BA in Politics with International Relations from the University of York. Her research focuses on Critical Security Studies, primarily human security and security in everyday practices. She is currently exploring the impact of climate change on people in southern Africa, focusing on the contestations between human and state security.

Schoutje C.S. Schouten holds an MLitt in Strategic Studies from the University of St Andrews and an MA in Philosophy from the University of Groningen. Her research focuses primarily on military ethics. She is a member of the Dutch National ThinkTank 2020.

\begin{abstract}
This article explores both individual and collective critical reflections on our involvement in the Threads, war and conflict project at the University of St Andrews. The article includes a collaborative section, followed by the authors' personal experiences of engaging with arpilleras and creating our own textiles on the themes of "family" and "home". The collaborative segment argues that arpilleras provided a voice for women in Chile to express their opposition to the military dictatorship of Augusto Pinochet. Touching on the concepts of women, textiles and the notion of "voice" in International Relations, we demonstrate how voice should be taken seriously in the field, and how creative media can challenge traditional expressions of voice.
\end{abstract}

Keywords: Conflict, Textiles, Threads, Voice, War, Women 


\section{Introduction}

Arpilleras became popular in Chile during the military dictatorship of Augusto Pinochet from 1973 to 1990, as a means to highlight the suffering caused by political repression and economic insecurity. Arpilleras were constructed in workshops run by women, known as arpilleristas, and presented an opportunity for these women to voice their opposition to the dictatorship. The arpilleras were simple textiles that were usually made from thick hessian canvases, adorned with colourful fabric to create flat images; three-dimensional figures, such as dolls, were occasionally attached to the canvases to represent unique personalities (LaDuke, 1983, p. 34). The materials were accessible to most women, in both financial and practical terms, which was important as many of the arpilleristas were of lower social class and dependent upon the income which was collected by selling the arpilleras (Adams, 2005, p. 546).

While arpilleristas spoke through a means which was traditionally considered feminine, the arpilleras became a testimony for the collective suffering of people in Chile (Moya-Raggio, 1984, p. 279). The Chilean arpilleras have been displayed all over the world as a documentary archive of human rights abuses, and have inspired works of art in other countries, such as Northern Ireland, Peru and Zimbabwe (Ulster University, 2012). By spreading the textiles across borders, the women gained global attention for their situation, 'making it impossible [for the outside world] to deny the regime's horrors and the lives it claimed' (The Museum of Latin American Art, 2019).

In this article, we analyse the connections between arpilleras and the concepts of women, textiles and "voice" in International Relations. We argue that arpilleras and arpillera workshops provided women in Chile a means to express their voices in opposition to the dictatorship of Augusto Pinochet, and we demonstrate how arpilleras disrupt traditional notions of voice as being limited to the spoken word. We then explore our personal reflections on our experiences from the Threads, war and conflict project at the University of St Andrews, each highlighting key themes which emerged during the workshops.

\section{Reflections on textiles, women and voice}

\section{Becoming visible}

Since the late 1980s, considerable progress has been made to incorporate the voices of women into the field of International Relations (IR). Critical Feminist scholars, such as Ann Tickner, Christine Sylvester and Cynthia Enloe, have demonstrated the complexities and importance of studying women in IR (Enloe, 1990; Tickner, 1992; Sylvester, 1994). These scholars have critiqued concepts traditionally used in the study of IR, uncovered new empirical knowledge using gender-based perspectives, and highlighted new or neglected subjects in the field (Lobasz and Sjoberg, 2012, p. 573). Scholars, however, have questioned whether the voices of women have been successfully represented, whether Feminist scholars are just 'talking to 
themselves', or else have highlighted a tendency to under- or mis-represent the experiences of women in the non-Western world (D'Costa and Lee-Koo, 2013, p. 451; Shepherd, 2013, p. 438). Despite the progress that has been made in making women visible in IR, they continue to be under-acknowledged, and are frequently viewed as being passive or submissive, often limiting their authority and their agency within the political arena (Matthews, 2002, p. 214). Arpilleras helped to make women in Chile more visible in politics by providing a means through which they could assert their voices.

"Voice" is naturally understood as an expression of agency and the sharing of one's perspective. Traditionally, the recognition of one's "voice" and the ability to share personal experiences has centred on the spoken word (Guillaume, 2013, p. 12). More broadly, "voice" has been defined in connection with concepts of participation and empowerment, and has been deemed 'essential in the constitution of social and political boundaries, identities and communities' (Guillaume, 2018, p. 476; Prouska and Psychogios, 2018, p. 885). Limiting an understanding of "voice" to the narrow definition of the spoken word is, therefore, deeply problematic, as it is silencing the visibility, participation and agency of women within IR.

Overcoming this problem, however, is not as simple as "adding" women into the study of IR; it requires a fundamental reworking of IR as a discipline to listen to the experiences and voices of women. In other words, 'agency needs to be rethought', redefined and broadened from simply denoting the spoken word (Parpart, 2010, p. 15). Archival records can play a fundamental role in this. Female voices are often excluded from archival records due to the patriarchal nature of many record-creating systems (Doolan, 2016, p. 10); this means that the archives contain 'archival silences', which leads to the symbolic annihilation of certain groups from them (Caswell, 2014, p. 36). By choosing what to store, what to discard, what to classify and how to classify it, as well as choosing what to make accessible and to whom, archives are political institutions and 'sites of power' (Jimerson, 2009, p. 2; Tesar, 2015, p. 102).

As researchers in the field, we ought to be aware of this. When conducting research, we should make an effort to report on the historical and political context in which a document was created (Subotic, 2020, p. 11). We should also think creatively about alternative archival sources other than official state archives, in order to illustrate a more nuanced view of people's lives and livelihoods (Subotic, 2020, p. 8). By including more "voices", and especially women's voices that have been 'silenced', we can achieve a more rounded sense of identity, which can have significant benefits for the study of IR (Cook, 2011, p. 185). An inclusion of arpilleras in archival collections would help fill the gendered silence within those traditional record-keeping practices. 


\section{From survival mechanism to political movement}

Arpilleras served a dual purpose for arpilleristas in Chile; producing the textiles presented an opportunity for extra income, and provided a way for the women to tell stories in protest against the Pinochet regime. The Pinochet regime created such an environment that lowerclass women had to act in order to provide for their families. The arpilleras, therefore, came into existence out of necessity (Council on Hemispheric Affairs, 2008; McCracken, 2011). Whilst making arpilleras together at workshops, the women found themselves able to talk freely about political and social issues. This feeling of liberation helped stir the women into the direction of a political movement via their arpilleras. For the Chilean women, the arpilleras became a form of resistance and protest. It gave them the opportunity to depict scenes which denounced the human rights violations of the Pinochet regime (Council on Hemispheric Affairs, 2008).

The textiles became a way for the women to tell their stories and share them with the world. Kept silent by the Pinochet regime, the Chilean women were 'denied the occasion, ability or tools to record their stories in any other way' (Doolan, 2016, p. 11). The arpillera workshops enabled women to become public actors, as they formed their own participation in the political process of democratisation (Boldt and White, 2011, pp. 34-35). Arpilleristas would not only use the arpilleras to express their emotions, but to document the violence they witnessed, as well as the unemployment, poverty and repression they experienced (Adams, 2013, p. ix; Bacic, 2015, p. 395). The textiles became a representation of a collective voice of female suffering, documenting part of the wider human rights movement in Chile (Moya-Raggio, 1984, pp. 278-279; Strauss, 2015, p. 381).

The power that these textiles harnessed was demonstrated by the fact that the Chilean authorities sought to punish those who created arpilleras (Bacic, 2015). The Pinochet regime felt threatened by the arpilleras and the women's voices represented in the textiles. These textiles provided an opportunity for expression and reclaiming of agency and voice for the women responsible for their creation. Whereas the voices of women have typically been understood in broad brushstrokes, omitting contextual backgrounds and individual circumstances (Mohanty, 1984, p. 344), the arpilleras demonstrate that agency can indeed be redefined, and the voices of individuals can be uniquely articulated, and evidently powerfully "heard", through these textiles.

\section{A visualisation of voice}

Whether depicting a single scene from a memory or framing a loved one's piece of clothing, arpilleras demonstrate the ability to share a piece of an individual's engagement with the world. Furthermore, each piece aims to tell a story and has a visual intention: to promote its creator's experiences and prevent them from happening to others. Arpilleras also work as a coping mechanism for trauma or to document a significant moment in the arpilleristas' lives. By this very nature, therefore, it is impossible to overlook the element of "voice" within the 
textiles. The arpilleras present the visualisation of "voice", which breaks beyond singular, contextual understandings and language barriers to share the experiences and lives of actual people. As Andrä et al. summarise, 'there is no single way to make sense of conflict textiles' visuality' (Andrä et al., 2020, p. 346).

With this understanding, an arpillera can no longer be viewed as a singular, stagnant piece but rather as an interactive one, in which a multitude of conversations can occur depending on the onlooker's interpretations and contextual background. Exhibiting arpilleras in collections further enhances this notion of the pieces being able to speak. While each piece has its own individual story to tell, exhibiting them together naturally places them in conversation with each other. They present multiple perspectives and experiences of displacement, migration and war, and 'facilitate dialogue, connection and action as a way forward from these confrontations' (Andrä et al., 2020, p. 351). The common exhibition of these pieces places stronger emphasis on and awareness of those voices, unifying them so they speak louder and have a more expansive impact on audiences. The collection highlights the ability of the textiles to speak collectively together and to one another, whether that be through common themes and narratives, or similarities in layout, style and materials adopted. The exhibition places a common thread through the collection of textiles, which fundamentally unifies many voices to convey collectively a wider response to subordination and political repression. In other words, 'each voice is a thread [...] many voices not one, cut from the same cloth or different' (Collins, 2016).

\section{Threads, war and conflict project}

In April 2019, a selection of arpilleras from the Conflict Textiles collection were exhibited at the University of St Andrews as part of a project entitled Threads, war and conflict. The project hosted a programme of events including textile workshops, in which the three authors of this paper participated together with five other women. During the workshops, we collectively engaged with and analysed the arpilleras in the exhibition. The arpilleras told the stories of the arpilleristas, their suffering, broken homes and lost families. In response to their stories, we created our own arpilleras on the themes of "family" and "home". Doing so, gave us a greater understanding of voice and agency, and how one's voice can be expressed through other channels than the spoken word. Here are our personal accounts of the project, in an effort to highlight how our voices were woven into our textiles.

\section{A sensory journey}

Seamlessly blending aesthetic beauty and emotive raw experiences to explore the personalities and life experiences the textiles shared was something I found breathtakingly powerful: a collection of silent and poignant beauty giving voice to life experiences through vibrant displays of creativity. 
Inspired by the exhibition, I wanted to explore the concept of a sensory experience within my own textile (see Image 1). Taking time to experience physically how fabrics felt, I considered colours, patterns, materials and shapes acknowledging how they made me feel and what they represented visually. I further composed and stitched a short piece of music to the back of my textile to incorporate an audible expression. This awareness of a sensory experience allowed me to acknowledge and explore my own voice within the arpillera.

Rachel

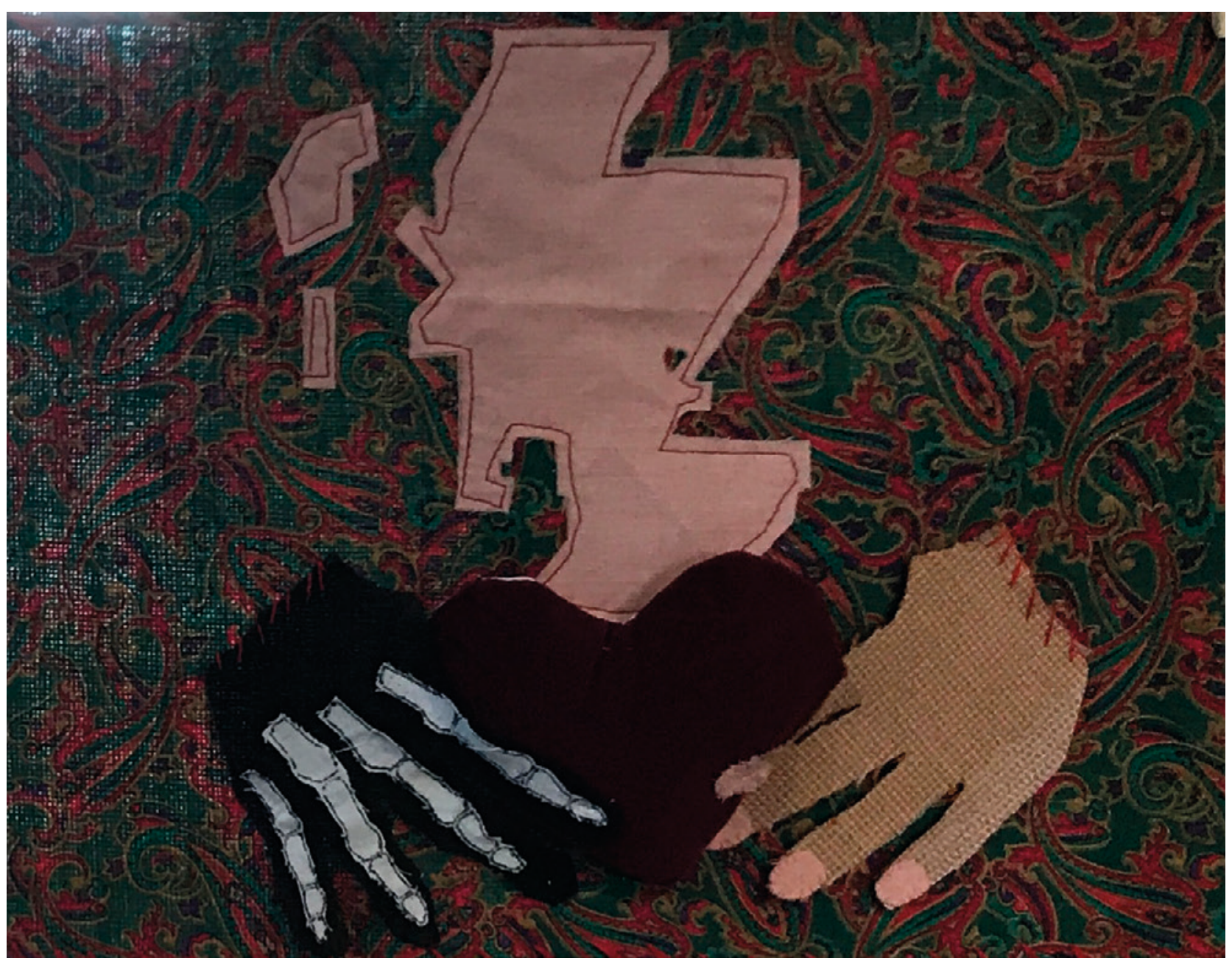

Image 1 - Rachel Beattie

\section{Expressions of emotion}

During the workshops, I was struck by the level of emotion which was expressed through the arpilleras. The arpilleras gave voices to feelings of anger, grief and hope during times of conflict and displacement. The arpilleristas' emotions regarding their families and homes were reflected in the arpilleras through depictions of their livelihoods and relationships being under threat from political repression and violence.

I tried to incorporate that expression of emotion into my own textile (see Image 2), which was inspired by a trip I took to Namibia when I was a teenager. The trip highlighted how much 
I valued being close to my family, and producing the textile gave me a chance to give voice to the experience of missing family, which enabled a deeper reflection on the arpilleras' narratives of loss.

Frankie

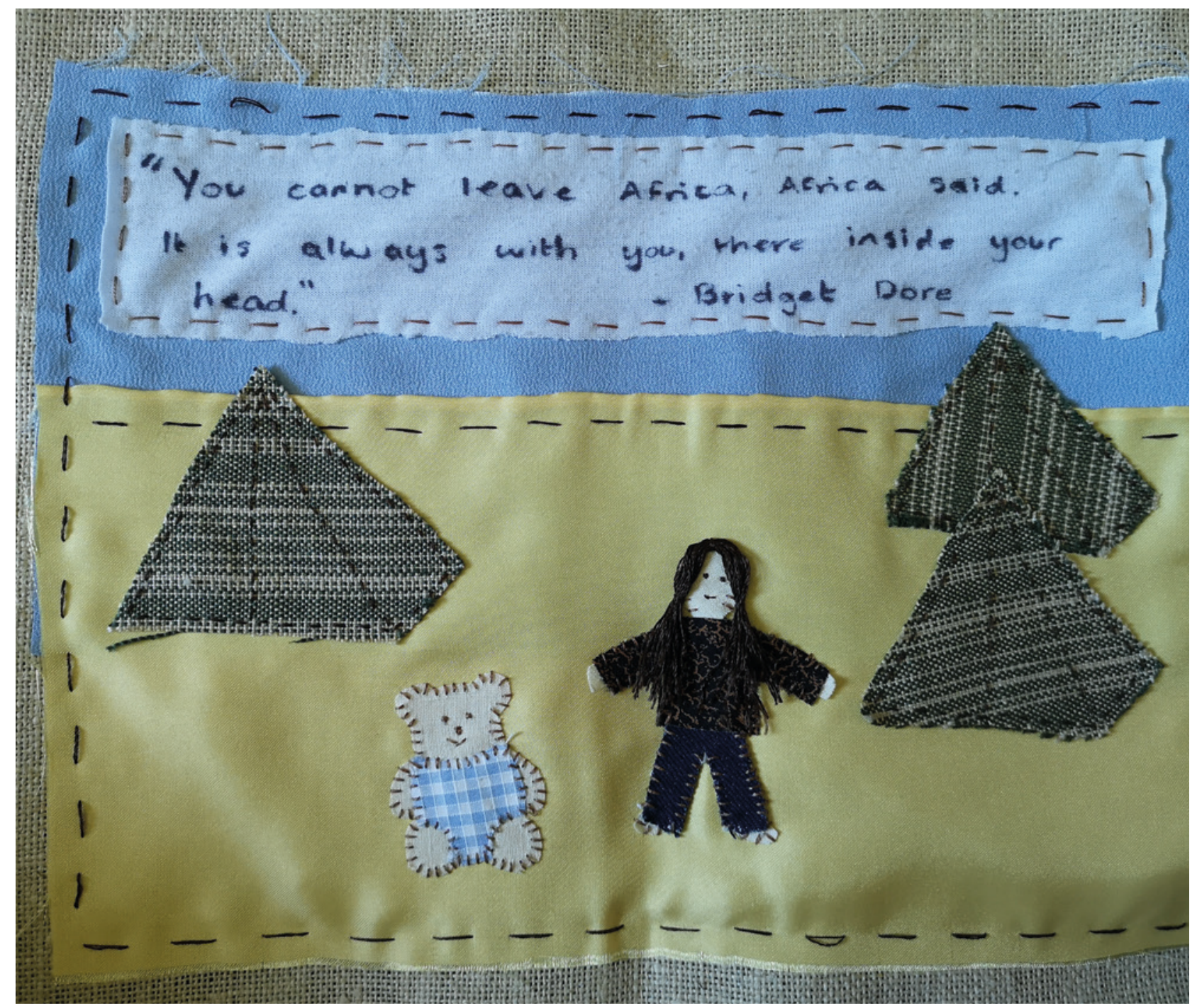

Image 2 - Frankie Copp

\section{In stark contrast}

As bright and colourful as the textiles are, so intense and heavy are the stories to which they give voice. Taking in the arpilleras, I got to experience part of the arpilleristas' lives. It made me realise how different their lives were from mine, and how fortunate I was as a little girl growing up in a safe and secure environment.

I wanted to give voice to that feeling of "protection" and security in my textile by depicting myself as a little girl with three "protectors": the family house, my mother and my father (see Image 3). This was my way of letting a voice be heard in reaction to the arpilleras, and sharing my wish that the arpilleristas could experience the security I felt as a child.

Schoutje 


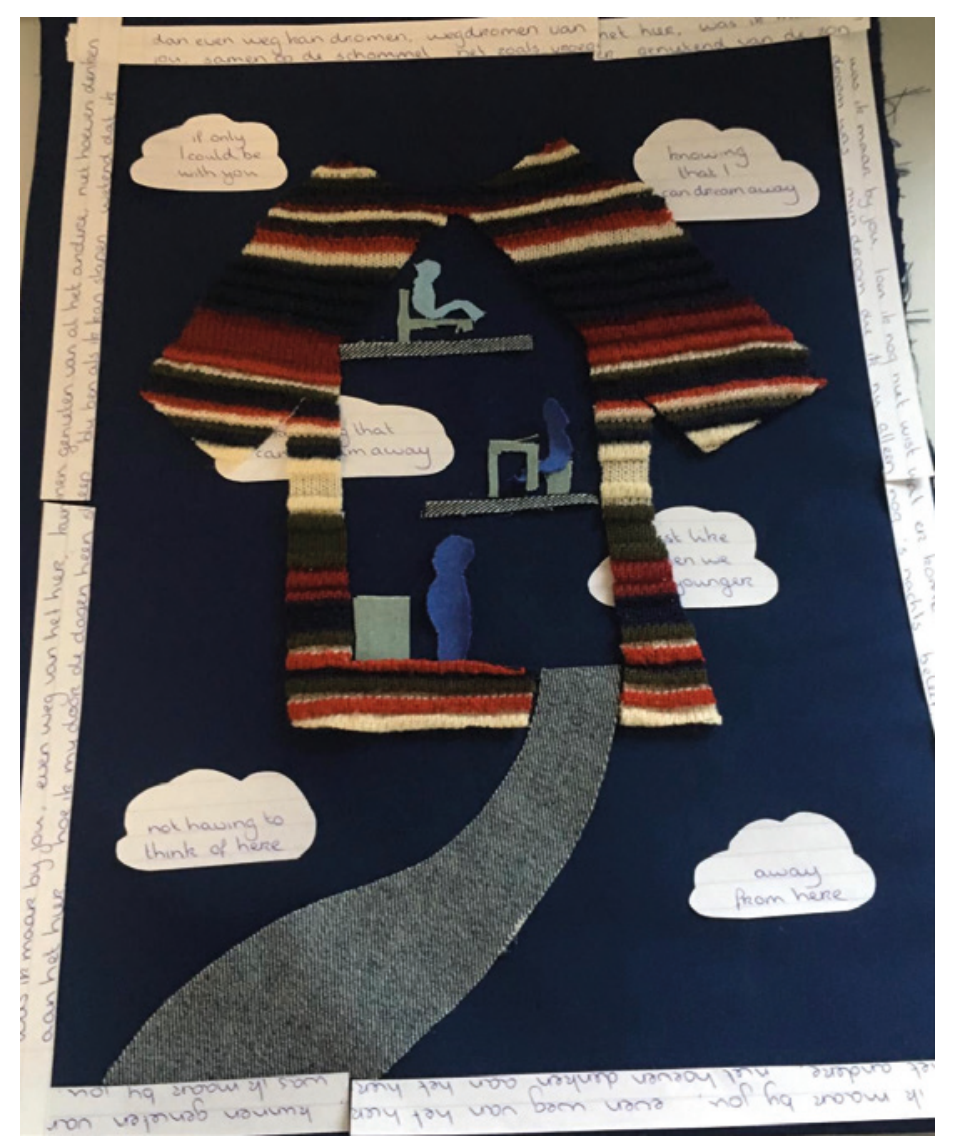

\section{Image 3 - Schoutje Schouten}

\section{Shared experiences}

For all three of us, the project provided an opportunity for reflection. The creation of the textiles asked us to go inward in silence, and to find our voices in response to the arpilleras and the stories behind them.

\section{What does this mean for the study of IR?}

In conclusion, the arpilleras provide an opportunity to rethink the passivity and relative invisibility of women within the study of IR. Using the arpilleras as theirvoices, the arpilleristas in Chile, as a group that had traditionally been overlooked and oppressed, resisted traditional gendered roles to reposition themselves as political agents. Conceptualising the arpilleras as the "voices" of women, creates a platform for reimagining and reclaiming the agency of women and subsequently a way of breaking gendered silences. It further creates a space to redefine "voice" beyond traditional understandings of the spoken word. This ultimately broadens the scope of voice to include a more multidimensional approach in which we can hear voices that would have previously been silenced. Thus, acknowledging the magnitude of power that the arpilleras contain has a wealth of potential for inspiring alternative methods for listening to the voices of those who have been traditionally oppressed or omitted from narratives. 
The arpilleras provide physical evidence of a "voice" to those who have been silenced. The process of creating a textile is, from our experience, highly personal and one which falls within the daily activities of many women around the world regarding sewing and working with fabrics. The ability for such an everyday activity to become a communicative tool of voice for the arpilleristas demonstrates the need for IR to diversify its understanding of how voice can be conveyed. The arpilleras highlight how "voice" cannot be singularly tied to notions of the spoken word, and challenges IR to broaden understandings of who can speak and how they speak. The creation and exhibition of arpilleras, such as in the Threads, war and conflict project, champion the empowerment of those who have been silenced and demands that the study of IR creatively reconsiders the agency, visibility and voices of women.

\section{References}

Adams, J. (2005) 'When art loses its sting: the evolution of protest art in authoritarian contexts', Sociological Perspectives, 48 (4), pp. 531-558.

Adams, J. (2013). Art against dictatorship: making and exporting arpilleras under Pinochet. Austin, TX: University of Texas Press.

Andrä, C., Bliesemann de Guevara, B., Cole, L. and House, D. (2020) 'Knowing through needlework: curating the difficult knowledge of conflict textiles', Critical Military Studies, 6 (3-4), pp. 341-359.

Bacic, R. (2015) 'Arpilleras in contested spaces', in Huhle, N. and Huhle, T. (eds), Die subversive Kraft der Menschenrechte: Rainer Huhle zum radikalen Jubilaum. Munich: GRIN Verlag GmbH, pp. 391-411.

Boldt, K. and White, T.J. (2011) 'Chilean women and democratization: entering politics through resistance as arpilleristas', Asian Journal of Latin American Studies, 24 (2), pp. 2744.

Caswell, M. (2014) 'Seeing yourself in history: community archives and the fight against symbolic annihilation', The Public Historian, 36 (4), pp. 26-37.

Collins, K. (2016) 'Woven into the fabric of the text: subversive material metaphors in academic writing', LSE Review of Books, 27 May [Online]. Available at: https://blogs.lse. ac.uk/1sereviewofbooks/2016/05/27/the-materiality-of-research-woven-into-the-fabric-ofthe-text-subversive-material-metaphors-in-academic-writing-by-katie-collins/ (Accessed: 11 January 2021). 
Cook, T. (2011) "WWe are what we keep, we keep what we are": archival appraisal past, present and future', Journal of the Society of Archivists, 32 (2), pp. 173-189.

Council on Hemispheric Affairs (2008) 'Chilean women's resistance in the arpillera movement', 19 June [Online]. Available at: https://www.coha.org/chilean-women $\%$ E2\%80\%99sresistance-in-the-arpillera-movement/ (Accessed: 2 August 2020).

D'Costa, B. and Lee-Koo, K. (2013) 'The politics of voice: feminist security studies and the Asia-Pacific', International Studies Perspectives, 14 (4), pp. 451-454.

Doolan, E. (2016) 'Textiles of change: how arpilleras can expand traditional definitions of records', InterActions: UCLA Journal of Education and Information Studies, 12 (1), pp. 1-15 [Online]. Available at: https://escholarship.org/uc/item/80j818zz (Accessed: 2 August 2020).

Enloe, C. (1990) Bananas, beaches and bases: making feminist sense of international politics. Berkeley: University of California Press.

Guillaume, X. (2013) 'The sound of silence: vice, security and the mundane' [Online]. Available at: https://www.sussex.ac.uk/webteam/gateway/file.php?name=guillaume-7-oct. pdf\&site=12 (Accessed: 13 August 2020).

Guillaume, X. (2018) 'How to do things with silence: re-thinking the centrality of speech to the securitization framework', Security Dialogue, 49 (6), pp. 476-492.

Jimerson, R.C. (2009) Archives power: memory, accountability, and social justice. Chicago, IL: Society of American Archivists.

LaDuke, B. (1983) 'Chile: embroideries of life and death', The Massachusetts Review, 24 (1), pp. 33-40.

Lobasz, J.K. and Sjoberg, L. (2012) 'The state of feminist security studies: a conversation Introduction', Politics \& Gender, 7 (4), pp. 573-576.

Matthews, J. (2002) 'An ambiguous juncture: racism and the formation of Asian femininity', Australian Feminist Studies, 17 (38), pp. 207-219.

McCracken, S. (2011) 'Arpilleras: a visual history of the poor under Pinochet', Prospect, 24 August [Online]. Available at: https://prospectjournal.org/2011/08/24/arpilleras-a-visualhistory-of-the-poor-under-pinochet/ (Accessed: 3 August 2020). 
Mohanty, C.T. (1988) 'Under western eyes: feminist scholarship and colonial discourses', Feminist Review, 30 (1), pp. 61-88.

Moya-Raggio, E. (1984) 'Arpilleras: Chilean culture of resistance', Feminist Studies, 10 (2), pp. 277-290.

Parpart, J.L. (2010) 'Choosing silence: rethinking voice, agency and women's empowerment', in Ryan-Flood, R. and Gill, R. (eds), Secrecy and silence in the research process: feminist reflections. New York: Routledge, pp. 15-29.

Prouska, R. and Psychogios, A. (2018) 'Do not say a word! Conceptualising employee silence in a long-term crisis context', The International Journal of Human Resource Management, 29 (5), pp. 885-914.

Shepherd, L.J. (2013) 'The state of feminist security studies: continuing the conversation', International Studies Perspectives, 14 (4), pp. 436-439.

Strauss, A. (2015) 'Treading the ground of contested memory: archivists and the human rights movement in Chile', Archival Science, 15 (4), pp. 369-397.

Subotic, J. (2020) 'Ethics of archival research on political violence', Journal of Peace Research, July, pp. 1-13.

Sylvester, C. (1994) Feminist theory and international relations in the postmodern era. Cambridge: Cambridge University Press.

Tesar, M. (2015) 'Ethics and truth in archival research', History of Education, 44 (1), pp. 101114.

The Museum of Latin American Art (2019) 'Arte, mujer y memoria: arpilleras from Chile' [Online]. Available at: https://molaa.org/arpilleras-online (Accessed: 2 August 2020).

Tickner, J.A. (1992) Gender in international relations: feminist perspectives on achieving global security. New York: Columbia University Press.

Ulster University (2012) Transforming threads of resistance: political arpilleras \& textiles by women from Chile and around the world, The Art of Conflict Transformation Event Series, 27 February [Online]. Available at: https://cain.ulster.ac.uk/quilts/exhibition/2012-02-27 Amherst/2012-02-27 Threads-Booklet-Small.pdf (Accessed: 13 August 2020). 